\title{
PENGARUH PENCAMPURAN KOTORAN TERNAK SEBAGAI MEDIA KULTUR TERHADAP PERTAMBAHAN POPULASI CACING TANAH (Lumbricus rubellus)
}

\author{
The Effect of Mixing Cattle Dung as a Culture Medium to the \\ Population of Earthworm (Lumbricus rubellus)
}

\author{
Satria Edi Putra, Iskandar Johan, Muhammad Hasby \\ Fakultas Pertanian Universitas Islam Riau, Jl. Kaharuddin Nasution 113, Pekanbaru 28284 \\ Telp: 0761-72126 ext. 123, Fax: 0761-674681 \\ [Diterima: Januari 2018; Disetujui: April 2018]
}

\begin{abstract}
This research aims to determine the effect of mixing cattle dung as a culture medium to the growing population of earthworms. The research was conducted for 42 days starting from 18 October to 28 November 2017 at the fish farming school hall of Agriculture Faculty of Islamic University Riau Pekanbaru. The worm tree used in this study was as many as 960 tail or 80 tail for each container. Worms are maintained for 42 days with different mixtures of medium, i,e, $100 \%$ P1 dung treatment, $\mathrm{P} 2$ cow-dung treatment $50 \%+50 \%$ buffalo dung, $50 \%$ cow dung $+50 \%$ goat dung, $50 \%$ cow dung $+50 \%$ chicken droppings. The research design was Completely Randomized Design with 4 treatments and 3 replications. The result of this research showed that the increase of population of earthworm with the mixing of cattle dung as culture media which conducted for 42 days is the best treatment of P2 as much as 4266 head/container, then the second one used was in treatment 3 as much as 1855 head/container, and the lowest increase of the population was at treatment P1 as much as $403 \mathrm{head} /$ container, and followed by treatment $\mathrm{P} 4$ as much as 575 head/ container.
\end{abstract}

Keywords: Earthworm (Lumbricus rubellus), Population growth

\begin{abstract}
ABSTRAK
Penelitian ini dilaksanakan selama 42 hari mulai tanggal 18 Oktober-28 November 2017 di Balai Benih Ikan (BBI) Fakultas Pertanian Universitas Islam Riau Pekanbaru. Penelitian ini bertujuan untuk mengetahui pengaruh pencampuran kotoran ternak sebagai media kultur terhadap pertambahan populasi cacing tanah (L. rubellus). Indukan cacing tanah (L. rubellus) yang digunakan pada penelitian ini sebanyak 960 ekor atau 80 ekor untuk masing-masing wadah. Cacing dipelihara selama 42 hari dengan campuran media yang berbeda-beda yaitu, pada perlakuan P1 kotoran sapi $100 \%$, perlakuan P2 kotoran sapi 50\% + kotoran kerbau 50\%, perlakuan P3 kotoran sapi 50\% + kotoran kambing 50\%, dan perlakuan P4 kotoran sapi 50\% + kotoran ayam 50\%. Rancangan penelitian menggunakan metode Rancangan Acak Lengkap (RAL) dengan 4 perlakuan dan 3 ulangan. Hasil penelitian adalah pertambahan populasi cacing tanah (L. rubellus) dengan pencampuran kotoran ternak sebagai media kultur yang dilaksanakan selama 42 hari yang terbaik terdapat pada perlakuan P2 sebanyak 4266 ekor/wadah, kemudian yang terbanyak kedua yaitu pada perlakuan P3 sebanyak 1855 ekor/wadah, dan yang paling sedikit pertambahan populasinya yaitu pada perlakuan P1 sebanyak 403 ekor/wadah, dan disusul oleh perlakuan P4 sebanyak 575 ekor/wadah.
\end{abstract}

Kata kunci: Cacing tanah (Lumbricus rubellus), Pertambahan populasi.

PENDAHULUAN

Dewasa ini, kegiatan usaha budidaya perikanan sangatlah diperlukan, mengingat potensi sumber daya alam dalam hal perikanan semakin menurun. Hal ini tidak lain disebabkan penangkapan ikan yang berlebihan, ilegal fishing, rusaknya ekosistem perairan 
dikarenakan banyaknya pembangunan dan industri. Oleh sebab itu kegiatan budidaya perikanan harus semakin dikembangkan untuk menjaga populasi ikan maupun permintaan masyarakat akan ikan.

Cacing tanah (L. rubellus) atau biasa disebut cacing Lumbricus bisa menjadi alternatif bagi para petani dan pembudidaya dalam kegiatan usaha budidaya perikanan, mengingat cacing ini memiliki kandungan protein yang cukup tinggi dan juga mudah dibudidayakan karena tidak memerlukan sarana dan prasarana yang biayanya mahal. Hermawan (2016) menyatakan bahwa cacing tanah (L. rubellus) mengandung kadar protein sangat tinggi sekitar $76 \%$. Kadar ini lebih tinggi dibandingkan daging mamalia $(65 \%)$ atau ikan (50\%). Untuk keperluan pasar ekspor, cacing tanah bukan hanya dijadikan sebagai pakan ternak, tetapi juga sebagai bahan baku bagi dunia perikanan.

Pada budidaya perikanan, cacing tanah (L. rubellus) sangat cocok digunakan sebagai pakan alami untuk pematangaan gonad induk ikan, mengingat kandungan proteinnya yang cukup tinggi. Tidak hanya dapat diberikan untuk induk ikan, cacing ini juga cocok diberikan pada benih ikan yang sangat membutuhkan protein tinggi agar dapat menciptakan benih ikan yang bermutu. Meskipun pemberiannya harus melalui proses penyincangan untuk menyesuaikan dengan ukuran mulut benih ikan.

Menurut Kristanto (2007) penyediaan benih bermutu dapat dilakukan dengan memperhatikan berbagai faktor salah satunya adalah manajemen pakan yang harus mencukupi kebutuhan gizi untuk proses prtumbuhan bagi ikan komoditas budidaya. Selanjutnya Chilmawati et al., dalam Purwanti et al., (2014) menambahkan penggunaan pakan cacing tanah dapat menurunkan biaya pakan buatan sebesar $28,84 \%$.

Dibalik kandungan proteinnya yang tinggi dan sangat cocok bagi dunia perikanan, cacing tanah (L. rubellus) juga mudah dibudidayaka karena perkembang biakannya yang sangat cepat. Cacing tanah (L. rubellus) dapat menjadi alternatif dalam meningkatkan perekonomian masyarakat, mengingat harga jualnya yang cukup tinggi dan banyaknya permintaan pasar baik nasional maupun
internasional.Permintaan pasar dalam dan luar negeri tidaklah sedikit mengingat cacing ini multimanfaat. Tak heran, budidaya cacing tanah (L. rubellus) memiliki prospek besar bahkan sebagai komoditi ekspor yang tinggi (Hermawan, 2016). Media untuk budidayanya pun juga sangat mudah dicari, yaitu limbah kotoran ternak mengingat kotoran ternak mudah dicari karena jarang digunakan selain hanya sebagai pupuk tanaman. Menurut Khairuman dan Amri (2009), semua media yang baik dalam budidaya cacing tanah adalah bahan organik serta mengandung protein, karbohidrat, vitain, dan mineral

\section{METODE PENELITIAN}

Penelitian dilaksanakan di BBI (Balai Benih Ikan) milik Universitas Islam Riau, jalan Kaharuddin Nasution Pemberhentian Marpoyan, Pekanbaru yang dilaksanakan selama 42 hari mulai 18 Oktober - 28 November 2017 setelah melakukan uji pendahuluan pada bulan Maret hingga April 2017.

Bahan - bahan yang digunakan pada peneitian ini yaitu, cacing Lumbricus rubellus sebanyak 960 ekor, kotoran kerbau, kotoran kambing, kotoran sapi, dan kotoran ayam yang diambil langsung dari tempat peternakan hewan tersebut, kemudian air yang digunakan untuk menyiram media cacing untuk tetap menjaga kelembaban media cacing tanah (L. rubellus).

Alat yang digunakan pada penelitian ini adalah nampan plastik yang digunakan sebagai wadah penelitian.Rak kayu yang digunakan untuk tempat meletakkan wadah penelitian. Alat semprotan air (hand sprayer) sebagai alat siram manual yang digunakan untuk mengatur kelembaban media penelitian, yaitu dengan cara menyiram media yang digunakan untuk penelitian. Sarung tangan digunakan untuk melindungi tangan dari media penelitian.Terpal digunakan sebagai alas kotoran hewan yang sedang dijemur atau di angin-anginkan pada saat persiapan media.Penggaris digunakan untuk mengukur besar media pada penelitian serta panjang cacing. $\mathrm{pH}$ meter yang digunakan untuk mengukur $\mathrm{pH}$, thermometer untuk mengukur suhu, dan moisture meter untuk mengukur kelembaban. 
Penelitian ini menggunakan Rancangan Acak Lengkap (RAL) block dengan 4 perlakuan dan 3 ulangan. Adapun perlakuan yang digunakan: $\mathrm{P} 1=$ Perlakuan menggunakan kotoran sapi $100 \%, \quad \mathrm{P} 2=$ Perlakuan menggunakan kotoran sapi $50 \%+$ kotoran kerbau $50 \%, \mathrm{P} 3=$ Perlakuan menggunakan kotoran sapi 50\% + kotoran kambing 50\%, P4 = Perlakuan menggunakan kotoran sapi 50\% + kotoran ayam $50 \%$.

Dalam penelitian ini hipotesis yang diajukan adalah : H0 : Tidak ada pengaruh perbedaan pencampuran kotoran kerbau dan sapi, kotoran sapi dan kambing, kotoran kerbau dan kambing terhadap pertambahan populasi cacing tanah (L. rubellus), H1 : Ada pengaruh perbedaan pencampuran kotoran kerbau dan sapi, kotoran sapi dan kambing, kotoran kerbau dan kambing terhadap pertambahan populasi cacing tanah (L. rubellus).

Pengukuran yang dilakukan meliputi bobot cacing menggunakan timbangan analitik pada berat awal penelitian dan berat di akhir penelitian.Penambahan populasi dihitung pada akhir penelitian menggunakan metode sampling dengan mengambil 4 titik pengambilan sampel di dalam wadah penelitian. Setelah itu menghitung jumlah cacing di setiap sampel lalu dirata-ratakan maka didapat jumlah populasi setelah dikurangi jumlah awal populasi cacing tanah (L.rubellus), susut media di hitung pada akhir penelitian yaitu pada hari ke 42 setelah dikurangi berat media awal.

\section{HASIL dan PEMBAHASAN}

\section{Pertambahan Populasi Cacing Tanah (L. rubellus)}

Pertambahan populasi cacing tanah $(L$. rubellus) pada masing - masing perlakuan dapat dilihat pada Tabel 1. Data tersebut merupakan data jumlah pertambahan populasi cacing tanah (L. rubellus) yang telah dihitung pada akhir penelitian dengan menghitung secara manual tanpa menggunakan alat khusus, serta membandingkan dengan jumlah indukan yang pertama dimasukkan pada awal penelitian yaitu 80 ekor indukan cacing tanah (L. rubellus).

Berdasarkan pada Tabel 1 dapat dilihat bahwa pertambahan populasi tertinggi yaitu pada perlakuan P2 dengan jumlah pertambahan populaasi mencapai 4266 ekor, kemudian disusul oleh P3 sebanyak 1855 ekor, kemudian P4 dengan jumlah pertambahan populasi sebanyak 575 ekor, dan yang paling sedikit jumlah populasinya pada P1 yaitu 403 ekor. Jika dilihat dari uji statistic pada Lampiran 2, ternyata berbeda nyata terhadap pertambahan populasi cacing tanah ( $L$. rubellus), dimana hasil uji coba ANAVA (sidik ragam) $F_{\text {hitung }}$ $4.01>\mathrm{F}_{\text {tabel }}(0.05) 3.47$ pada tingkat ketelitian $95 \%$.

Tabel 1. Rerata Pertambahan Populasi Cacing Tanah (L. rubellus) pada Masing - masing Perlakuan (ekor).

\begin{tabular}{crccr}
\hline \multirow{2}{*}{ Ulangan } & \multicolumn{4}{c}{ Perlakuan (ekor) } \\
\cline { 2 - 5 } & P1 & P2 & P3 & P4 \\
\hline 1 & 442 & 4.489 & 1.424 & 564 \\
2 & 493 & 4.533 & 1.936 & 475 \\
3 & 274 & 3.776 & 2.205 & 686 \\
Jumlah & 1.209 & 12.798 & 5.565 & 1.725 \\
\hline Rerata & $\mathbf{4 0 3}$ & $\mathbf{4 . 2 6 6}$ & $\mathbf{1 . 8 5 5}$ & $\mathbf{5 7 5}$ \\
\hline
\end{tabular}

Pada Gambar 1 perlakuan P2 yang menggunakan kotoran sapi $50 \%+$ kotoran kerbau 50\%, pertambahan populasi cacing sangat bagus dan merupakan perlakuan yang tertinggi pertambahan populasinya. Rata-rata jumlah cacing pada setiap perlakuan P2 yaitu 4266 ekor/wadah. Selain itu, media penelitian yang digunakanpun lebih terurai dengan bagus dan sudah tidak berbentuk kotoran ternak lagi, tapi sudah berbentuk kascing keseluruhannya, tekstur medianyapun sudah menjadi lembut dan poros, tidak seperti media yang pertama dimasukkan yang berbentuk padat. Selain itu, perlakuan P2 memiliki kandungan protein yang tidak terlalu tinggi dan sesuai untuk cacing. 


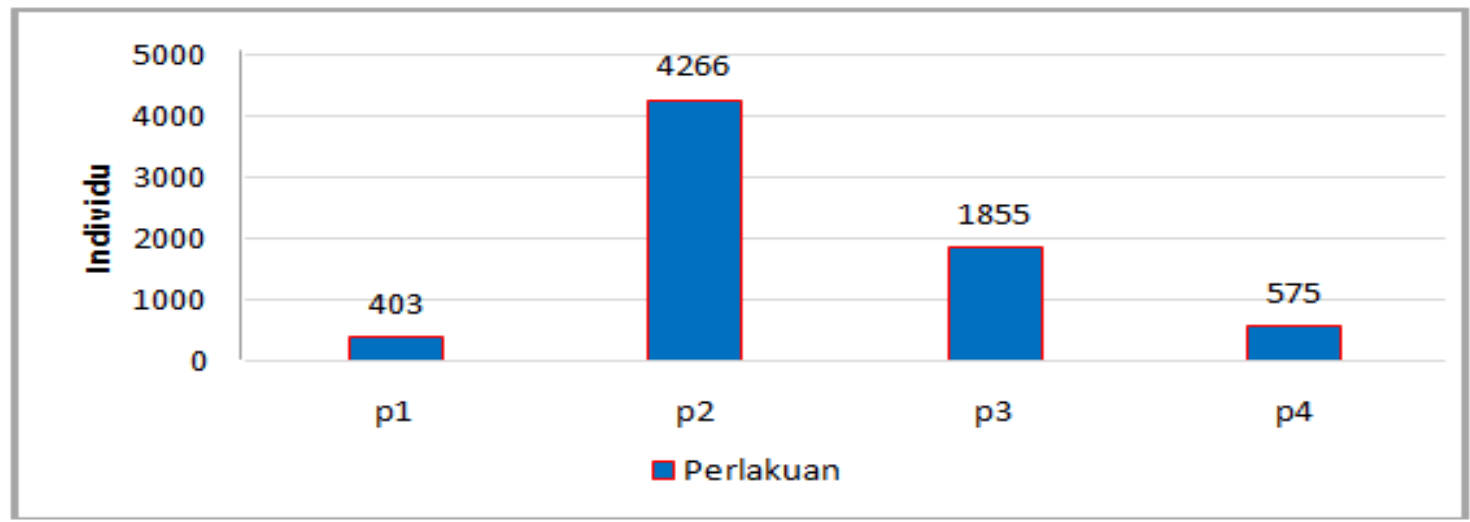

Gambar 1. Pertambahan populasi cacing tanah (L. rubellus) diakhir penelitian

Menurut Sihombing dalam Nur et al (2016) menjelaskan bahwa kandungan protein yang baik untuk cacing tanah berkisar antara 9$15 \%$. Astuti dalam Pangestika et al., (2016) menambahkan pemberian pakan yang memiliki kandungan protein tinggi $(>15 \%)$ tidak akan memberikan hasil yang baik dan membuat cacing tanah keracunan.

Kemudian perlakuan P3 yaitu pencampuran kotoran sapi $50 \%+$ kotoran kambing 50\%, menjadi perlakuan yang tertinggi kedua pertambahan populasinya karena tekstur media yang juga tidak padat dan halus. Perlakuan P1 yang hanya menggunakan kotoran sapi tanpa pencampuran bahan lain menjadi perlakuan yang paling sedikit jumlah pertambahan populasinya, karena media yang digunakan menjadi padat sehingga tidak disukai oleh cacing dan menyulitkan cacing untuk melakukan pergerakan. Palungkun (1999) menjelaskan bahwa media harus gembur dan tidak mudah memadat dan mengandung zat makanan yang cukup.
Kemudian perlakuan P4 yaitu pencampuran kotoran sapi 50\% + kotoran ayam $50 \%$,menjadi perlakuan terendah kedua. Hal ini disebabkan cacing kurang menyukai media ini karena kotoran ayam yang digunakan sebagai pencampuran media mengandung serbuk kayu dengan tekstur yang kasar sehingga tidak bisa dimakan dan dicerna oleh cacing. Erni dalam Nur et al., (2000) menambahkan bahwa tekstur media yang berserat dapat menyebabkan cacing tanah kesulitan mengonsumsi media.

Kegemburan media juga berpengaruh, karena jika media gembur maka akan memudahkan pergerakan cacing tanah ( $L$. rubellus) dalam melakukan pergerakan. Media yang gembur juga memudahkan oksigen untuk masuk kedalam media, jika media mudah memadat maka kebutuhan oksigen bagi cacing tanah tanah (L. rubellus)akan terbatas. Data jumlah kokon, juvenil, dan immature pada masing-masing perlakuan dapat dilihat dalam bentuk grafik pada Gambar 2.

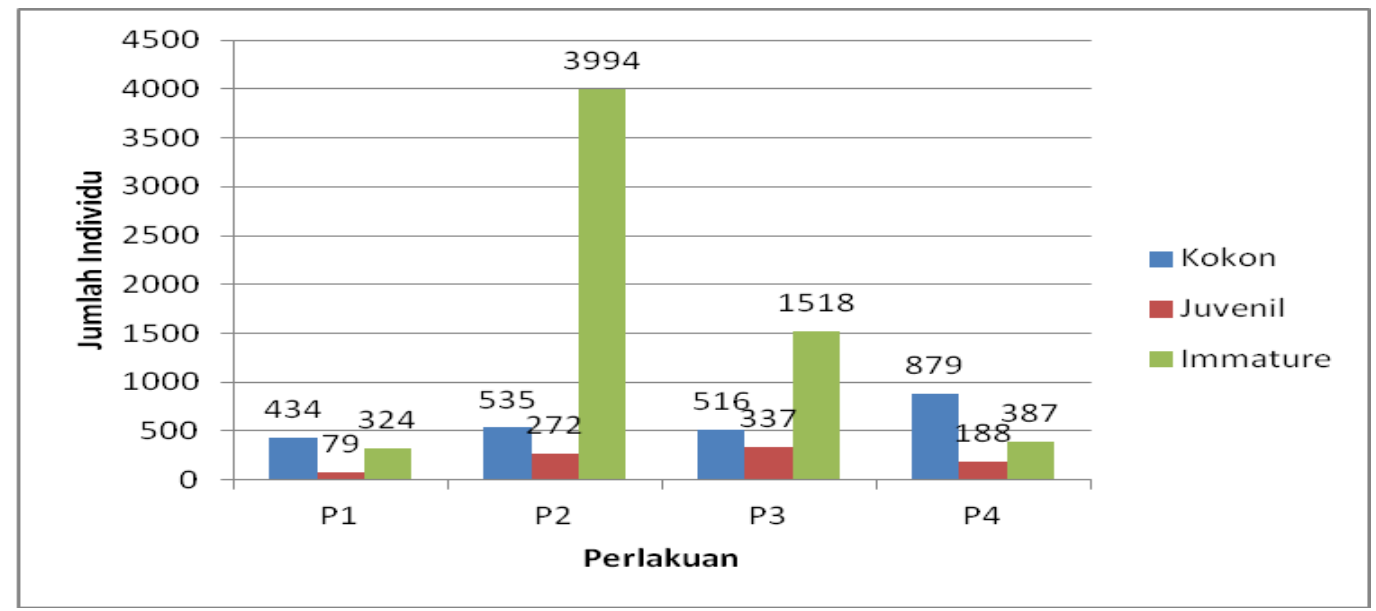

Gambar 2. Histogram Rerata Jumlah Kokon, Juvenil, dan Immature Cacing Tanah (L. rubellus) pada Masing-masing Perlakuan selama penelitian. 
Perlakuan P1 merupakan perlakuan yang memiliki jumlah kokon sebanyak 434 butir dan juvenile paling sedikit yaitu 79 ekor, hal ini disebabkan karena media yang dipakai tidak disukai cacing dan menyulitkan cacing tanah $(L$. rubellus) untuk melakukan reproduksi karena medianya mudah memadat.

Kemudian perlakuan P2 merupakan perlakuan yang memiliki kokon dan juvenile terbanyak kedua dengan jumlah kokon sebanyak 575 butir dan juvenile sebanyak 272 ekor. Pada media ini perkembangan dan reproduksi cacing sangat cepat dan kokon yang dihasilkan juga banyak. Selain itu, perlakuan P2 juga memiliki jumlah immature tertinggi diantara perlakuan yang lain yaitu sebanyak 3994 ekor, hal ini dikarenakan cacing tanah (L. rubellus) sangat menyenangi medianya yang berupa campuran kotoran sapi 50\% + kotoran kerbau 50\%.

Perlakuan P3 merupakan perlakuan yang memiliki jumlah immature terbanyak kedua setelah perlakuan P2, yaitu dengan jumlah immature sebanyak 1518. Pada perlakuan ini media yang dipakai berupa kotoran sapi $50 \%+$ kotoran kambing 50\% juga disenangi oleh cacing karena tekstur media yang gembur dan juga dapat mempertahankan kelembaban.

Perlakuan P4 menjadi perlakuan yang memiliki jumlah kokon terbanyak yaitu sebanyak 879 butir kokon. Ini dikarenakan kokon yang dihasilkan pada media ini menetas lebih lama dibandingkan perlakuan lain. Lambatnya penetasan kokon dipengaruhi oleh media yang memakai kotoran ayam sebagai campuran kotoran sapi memiliki kadar amoniak yang tinggi. Mashur dalam Pradinasari (2017), menjelaskan bahwa produksi kokon selain dipengaruhi oleh media, juga dipengaruhi oleh faktor lingkungan seperti $\mathrm{pH}$, kelembaban, suhu, dan ketersediaan pakan.

\section{Parameter Media yang Diukur}

Parameter media kultur yang diukur pada penelitian ini meliputi pengukuran suhu, derajat keasaman $(\mathrm{pH})$, dan kelembaban seperti pada Tabel 2.

Tabel 2. Parameter Pengamatan Pengukuran Media Kultur Selama Penelitian

\begin{tabular}{lccc}
\hline \multicolumn{4}{c}{ Parameter pengamatan media } \\
\hline \multicolumn{1}{c}{ Parameter } & Kisaran angka & Kelayakan & Sumber \\
\hline Suhu $\left({ }^{\circ} \mathrm{C}\right)$ & $24-29$ & $15-25$ & Hermawan, 2014 \\
Derajat keasaman $(\mathrm{pH})$ & $6,5-7$ & $6-7,2$ & Juhastantie, 2000 \\
Kelembaban $(\mathrm{RH})$ & $5-10$ & $15-30 \%$ & Fefritaet al., 2015 \\
\hline
\end{tabular}

Pada Tabel 2, dapat dilihat bahwa data pengukuran suhu selama penelitian yaitu berkisar antara $24-29^{\circ} \mathrm{C}$, keasaman $(\mathrm{pH})$ berkisar antara 6,5-7. Menurut Aziz dalam Pangestika et al., (2016) penyesuaian suhu media, $\mathrm{pH}$ media, dan kelembapan media juga faktor yang mempengaruhi kehidupan cacing tanah. Menurut Puspitasari dalam Astuti (2001) $\mathrm{pH}$ optimum untuk pertumbuhan dan perkembangbiakan cacing tanah (L. rubellus) adalah 6,8-7,2.

Kelembaban pada media berkisar antara 5-10 yang diukur dengan moisture meter atau alat pengukur kelembaban. Rukmanadalam Febrita et al., (2015) kelembapan yang baik untuk cacing tanah antara 15\%$50 \%$.Kelembapan tanah terlalu tinggi dapat menyebabkan cacing berwarna pucat dan bisa mengalami kematian. Sebaliknya apabila kelembaban terlalu rendah cacing tanah akan bergerak kemedia yang lembab.

\section{KESIMPULAN}

Dari hasil penelitan yang telah dilakukan, dapat disimpulkan sebagai berikut:

1. Perlakuan 2 (P2) menjadi perlakuan yang terbaik dan terbanyak tingkat pertambahan populasinya yaitu sebanyak 4266 ekor/wadah. Sedangkan yang paling sedikit jumlah pertambahan populasinya terdapat pada perlakuan 1 (P1) yaitu sebanyak 403 ekor/wadah.

2. Pencampuran media yang terbaik juga pada perlakuan P2 karena memiliki tekstur yang halus sehingga mudah dikonsumsi oleh cacing. Selain itu medianyapun poros dan sangat disukai oleh cacing karena cacing dapat leluasa melakukan pergerakan. 
3. Analisa variansi menunjukan bahwa $F_{\text {hitung }}$ $4.01>\mathrm{F}_{\text {tabel }}(0.05)$ 3,47 dimana pencampuran kotoran ternak sebagai media kultur terhadap pertambahan populasi cacing tanah (L. rubellus) berbeda nyata.

\section{DAFTAR PUSTAKA}

Astuti, N. D. 2001. Pertumbuhan dan Perkembangan Cacing Tanah ( $L$. rubellus) dalam Media Kotoran Sapi yang Mengandung Tepung Darah [skripsi]. Institut Pertanian Bogor. Bogor.

Febrita, E., Darmadi, dan E. Siswanto. 2015. Pertumbuhan Cacing Tanah ( $L$. rubellus ) Dengan Pemberian Pakan Buatan untuk Mendukung Proses Pembelajaran Pada Konsep Pertumbuhan dan Perkembangan Invertebrata. Jurnal BiogenesisVol. 11(2). Universitas Riau. 169 - 176 hal.

Hermawan, R. 2016. Usaha Budidaya Cacing Lumbricus Multiguna dan Prospek Ekspor Tinggi.Pustaka baru press.Yogyakarta.174 hal.

Khairuman dan K. Amri. 2009. Mengeruk Untung dari Beternak Cacing. Agro Media Pustaka. Jakarta. 79 hal.

Kristanto, A. H. 2007. Penguasaan Tekhnologi Budidaya untuk Menghasilkan Benih Ikan Air Tawar.Balai Riset Perikanan Air Tawar.30 hal.

Nur, J. Z,. Hasyim, S. Santoso. 2016. Pengaruh Pemberian Ampas Tahu dan Kulit Pisang Kepok Musa Acuminata Sebagai Pakan Terhadap Pertumbuhan dan Perkembangbiakan Cacing Tanah (Lumbricus rubellus). Universitas Hasanuddin.

Palungkun, R. 1999. Sukses Beternak Cacing Tanah (L. rubellus). Penebar Swadaya. Jakarta. 80 hal.

Pangestika, D.S., Nurwidodo, dan L. Chamisijatin, 2016. Pengaruh Pemberian Pakan Limbah Baglog Jamur Tiram Putih (Pleurotus ostreatus) Dan Kotoran Ayam Terhadap Pertumbuhan dan Produksi Kokoon Cacing Tanah (L. rubellus) Sebagai Sumber Belajar Biologi. Jurnal Pendidikan Biologi Indonesia.Universitas Muhammadyah Malang. Malang. 168-179 hal.
Pradinasari., A. 2017. Pengaruh Kombinasi Media Serbuk Gergaji Batang Pohon Kelapa (Cocos nucifera, L.) dan Rumput Manila (Zoysia matrella) terhadap Pertumbuhan dan Produksi Kokon Cacing Tanah (Lumbricus rubellus). Skripsi. FMIPA-UNY

Purwati. S. C, Suminto. A, dan Sudaryono. 2014. Gambaran Profil Darah Ikan Lele Dumbo (Clarias gariepinus) Yang Diberi Pakan Dengan Kombinasi Pakan Buatan Dan Cacing Tanah (L. rubellus). Universitas Diponegoro. Semarang. 53-60 hal. 